\title{
The hormonal status modulates the effect of neurokinin A on prolactin secretion in female rats
}

\author{
D Pisera, S Theas, A De Laurentiis, M Lasaga, B Duvilanski and \\ A Seilicovich
}

Centro de Investigaciones en Reproducción, Facultad de Medicina, Universidad de Buenos Aires, Buenos Aires, Argentina

(Requests for offprints should be addressed to D Pisera, Centro de Investigaciones en Reproducción, Facultad de Medicina, Piso 10, Buenos Aires (1121), Argentina)

\begin{abstract}
We have previously reported that neurokinin A (NKA), a tachykinin closely related to substance $\mathrm{P}$, increases the release of prolactin (PRL) from the anterior pituitary gland of male rats, but not from pituitaries of ovariectomized (OVX) female rats. In this study, we evaluated the influence of estrogens in the action of NKA on PRL secretion in female rats. NKA stimulated the in vitro release of PRL from pituitary glands of OVX-chronically estrogenized rats, and of proestrus and estrus rats, but had no effect in anterior pituitaries of diestrus rats. In addition, we observed that cultured anterior pituitary cells of OVX rats responded to NKA only when they were incubated for 3 days in the presence of estradiol $10^{-9} \mathrm{M}$. This effect was blocked by L-659,877, an NK-2 receptor antagonist. We
\end{abstract}

also studied the action of NKA on PRL release during lactation. The response of anterior pituitary cells to NKA was variable over this period. The maximal sensitivity to NKA was observed at day 10 of lactation. Furthermore, the blockade of endogenous NKA by the administration of an anti-NKA serum to lactating rats reduced the PRL surge induced by the suckling stimulus. These results show that the responsiveness of the anterior pituitary gland of female rats to NKA is modulated by the endocrine environment, and suggest that NKA may participate in the control of PRL secretion during the estrus cycle and lactation.

Journal of Endocrinology (1998) 159, 389-395

\section{Introduction}

Secretion of prolactin (PRL) from the anterior pituitary gland is regulated by both inhibitory and excitatory chemical signals. Many peptides, such as thyrotropinreleasing hormone (TRH), oxytocin, vasoactive intestinal peptide (VIP), angiotensin II and the tachykinin, substance P, stimulate PRL release at the pituitary level (Kordon et al. 1994). Our previous studies have shown that neurokinin A (NKA), another tachykinin closely related to substance $\mathrm{P}$, may act as a stimulatory factor in the control of PRL release. We have observed that the blockade of endogenous NKA by the administration of an anti-NKA serum (ANKA) reduced the hyperprolactinemia induced by estradiol in ovariectomized (OVX) rats and decreased the PRL surge in proestrus rats (Pisera et al. 1991). The effect of NKA on PRL release is exerted, at least in part, at the pituitary level, as this peptide stimulates PRL secretion from incubated anterior pituitaries of male rats (Pisera et al. 1994). Moreover, the in vitro blockade of endogenous NKA by the addition of ANKA to the incubation medium inhibits basal and NKA-induced PRL release, suggesting that the intrapituitary NKA may participate in the control of PRL secretion in male rats. However, neither NKA nor ANKA has significant effects on in vitro secretion of PRL from pituitary glands of OVX rats (Pisera et al. 1994). This sex difference in the in vitro effect of NKA on PRL release could result from the different hormonal environment. In fact, the in vivo effects of ANKA in female rats were observed only under conditions of high concentrations of estradiol (Pisera et al. 1991).

The effects of tachykinins are exerted through their interaction with three receptor subtypes, named NK-1, NK-2 and NK-3. These multiple tachykinin receptors have been identified in peripheral organs using bioassay and radioligand binding methods, and confirmed through the development of selective antagonists and the molecular cloning of the three receptor proteins (Maggi 1995). In view of the fact that NKA preferentially binds to NK-2 receptors, it is likely that this receptor subtype is involved in the neuroendocrine effects of NKA.

As it has been suggested that the effects of tachykinins on anterior pituitary hormonal secretion seem to depend on the gonadal hormone milieu (Kalra et al. 1992, Sahu \& Kalra 1992, Shamgochian \& Leeman 1992), we designed a study to investigate the possible role of estrogens in the in vitro pituitary responsiveness to NKA in female rats, and 
the influence of lactation on the effect of NKA on PRL release. In addition, we evaluated the involvement of NK-2 receptors (with which NKA displays greater affinity) in the action of NKA on PRL secretion, utilizing a specific NK-2 receptor antagonist, L-659,877 (Maggi 1995).

\section{Materials and Methods}

\section{Drugs}

All drugs were obtained from Sigma Chemical Co., St Louis, MO, USA, except fetal calf serum (GenSa, Buenos Aires, Argentina), NKA (Peninsula Laboratories, Inc., Belmont, CA, USA) and L-659,877 (Research Biochemicals International, Natick, MA, USA).

\section{Animals}

Wistar rats were bred at our own breeding laboratory. The animals were maintained in accordance with the NIH Guide for the Care and Use of Laboratory Animals, under controlled conditions of light (12 h light : $12 \mathrm{~h}$ darkness) and temperature $\left(20-25^{\circ} \mathrm{C}\right)$, with water and food available ad libitum. Adult rats weighing 200-250 g were used. In experiments in which cyclic female rats were used, the animals were monitored by daily vaginal smears. Rats with three or more normal consecutive estrus cycles were used. When OVX rats were used, the animals were ovariectomized under ether anesthesia 2 weeks before being killed.

\section{Estradiol treatment}

Female rats were implanted under the skin of the back with Silastic capsules (length $20 \mathrm{~mm}$, outer diameter $2 \mathrm{~mm}$ ) containing $1 \mathrm{mg} 17 \beta$-estradiol at the time of ovariectomy. Control OVX rats were implanted with empty capsules. The animals were killed 2 weeks later.

\section{Anti-NKA serum}

Preparation of the anti-NKA serum (ANKA) was as previously reported (Pisera et al. 1991). Cross-reactivity with other mammalian tachykinins was $0.78 \%$ for substance $\mathrm{P}, 1.56 \%$ for neurokinin B and $60 \%$ for neuropeptide $\mathrm{K}(\mathrm{NPK})$. NPK is an $\mathrm{NH}_{2}$-terminally extended form of NKA and hence its high cross-reactivity with the anti-NKA serum was expected.

\section{Suckling-induced PRL surge}

Pregnant rats were housed individually. On the day of parturition (assigned as day 1 of lactation), the litter size was reduced to eight pups per rat, to ensure a similar suckling stimulus. In the morning of day 8 of lactation, the rats were separated from their pups for $5 \mathrm{~h}$ and then they were reunited. This procedure was repeated on the following 2 days. The day before the experiment, the rats were injected by the tail vein with ANKA $(250 \mu \mathrm{l})$ or normal rabbit serum (NRS, $250 \mu \mathrm{l}$ ) under light ether anesthesia. On the day of the experiment, the mothers were separated from their pups for $5 \mathrm{~h}$, and then the offspring were returned to suckle for a period of $30 \mathrm{~min}$. After the end of this suckling period, the mothers were killed by decapitation. Another group of mothers were separated from their pups for $5.5 \mathrm{~h}$ and then decapitated (non-suckled control). Blood was collected from the trunk and serum was separated from each sample and stored at $-20{ }^{\circ} \mathrm{C}$ until required for analysis for PRL.

\section{Incubation of anterior pituitary glands}

The animals were killed by decapitation and the anterior pituitaries were removed and cut longitudinally into halves. One hemipituitary per tube was preincubated for $60 \mathrm{~min}$ in $1 \mathrm{ml} \mathrm{Krebs-Ringer} \mathrm{bicarbonate} \mathrm{buffer} \mathrm{(KRB),}$ $\mathrm{pH} 7 \cdot 4$, containing $10 \mathrm{mM}$ glucose, $25 \mathrm{mM}$ Hepes, $0 \cdot 1 \%$ BSA, $0 \cdot 1 \mathrm{mM}$ bacitracin and $1 \mathrm{mM}$ ascorbic acid, at $37^{\circ} \mathrm{C}$ in an atmosphere of $95 \% \quad \mathrm{O}_{2}-5 \% \quad \mathrm{CO}_{2}$, with constant shaking. After this period, the hemipituitaries were incubated for $60 \mathrm{~min}$ in $1 \mathrm{ml}$ fresh KRB with or without NKA. At the end of the incubation, the media were aspirated and kept frozen at $-20{ }^{\circ} \mathrm{C}$ until required for assay for PRL. Protein concentration in tissue homogenates was determined by the method of Lowry et al. (1951). The concentration of PRL in the incubation medium was expressed as $\mu \mathrm{g} / \mathrm{mg}$ protein.

\section{Anterior pituitary cell culture}

The animals were killed by decapitation and the anterior pituitary glands dissected out under sterile conditions. The glands were washed several times with Dulbecco's Modified Eagle's Medium (DMEM) and cut in small fragments. The slices were incubated successively in DMEM-BSA $(3 \mathrm{mg} / \mathrm{ml})$ containing trypsin (Type XII-S from bovine pancreas, $5 \mathrm{mg} / \mathrm{ml}$ ), DNAse (Deoxyribonuclease II, Type V from bovine spleen, $1 \mathrm{mg} / \mathrm{ml}$ ) and trypsin inhibitor (Type II-S from soybean, $1 \mathrm{mg} / \mathrm{ml}$ ) for enzymatic digestion. The cells were finally dispersed by extrusion through a Pasteur pipette in KRB without $\mathrm{Ca}^{2+}$ and $\mathrm{Mg}^{2+}$ and suspended in DMEM supplemented with $2.5 \%$ fetal calf serum (FCS), $10 \mu \mathrm{l} / \mathrm{ml}$ MEM aminoacids, $2.5 \mu \mathrm{g} / \mathrm{ml}$ amphotericin $\mathrm{B}, 25 \mu \mathrm{g} / \mathrm{ml}$ gentamicin and $2 \mathrm{mM}$ glutamine (DMEM-S). When cells of OVX rats were used, FCS was replaced by FCS adsorbed with dextran-coated charcoal (DMEM-AS). The cells were seeded onto 96-well tissue culture plates (80 000 cells $/ 0 \cdot 2 \mathrm{ml} /$ well) and cultured in DMEM-S or DMEM-AS for 3 days in a humidified atmosphere of 5\% 
$\mathrm{CO}_{2}-95 \%$ air at $37^{\circ} \mathrm{C}$. In order to investigate the in vitro effects of estrogens, anterior pituitary cells from OVX rats were cultured for another 3 days in DMEM-AS with $17 \beta$-estradiol $10^{-9} \mathrm{M}$ or vehicle (ethanol, final dilution $0 \cdot 0001 \%)$. After the culture period, the cells were washed twice with $\mathrm{KRB}$ and incubated for $60 \mathrm{~min}$ in $0 \cdot 2 \mathrm{ml} \mathrm{KRB}$ alone (control) or KRB plus test substances. At the end of the incubation period, the medium was aspirated, centrifuged at 1000 r.p.m. for $5 \mathrm{~min}$ and stored at $-20{ }^{\circ} \mathrm{C}$ until required for determination of PRL. The concentration of PRL in the incubation medium was expressed as ng/well. Because cultures of anterior pituitary cells from lactating rats were not performed simultaneously, basal PRL secretion showed variability among the different days of lactation; hence the concentration of PRL in the media of these experiments is shown as a percentage of respective control values.

\section{Prolactin radioimmunoassay}

PRL was measured by a double-antibody RIA method with reagents distributed by The National Hormone and Pituitary Program (Baltimore, MD, USA). RP-3 was used as reference preparation and NIDDK-anti-rPRL-S-9 as antiserum ( $\left.\mathrm{ED}_{50}: 0.54 \mathrm{ng} \mathrm{RP}-3\right)$. The cross-reactivity with other pituitary hormones was negligible. The intraand interassay coefficients of variations were less than $9 \%$.

\section{Statistics}

Data were expressed as means \pm S.E.M. The significance of the differences between means was determined by unpaired or paired Student's t-test, one-way analysis of variance (ANOVA) followed by Dunnett's test, or two-way ANOVA followed by multiple comparison Tukey's test.

\section{Results}

\section{Effect of NKA on PRL release from anterior pituitaries of cyclic female rats and OVX-estrogen-treated rats}

To evaluate the involvement of estrogens in the pituitary response to NKA in female rats, we studied the effect of NKA on the in vitro PRL secretion from halved anterior pituitaries of cyclic female rats and OVX rats treated chronically with estradiol. Female rats in different stages of the estrus cycle were killed in the afternoon (between 1400 and $1500 \mathrm{~h}$ ). One half of each anterior pituitary was incubated for $60 \mathrm{~min}$ with NKA $\left(10^{-7} \mathrm{M}\right)$, and the other half was incubated with KRB alone. In addition, anterior pituitaries of OVX and OVX-estrogen-treated rats were incubated with or without NKA $\left(10^{-7} \mathrm{M}\right)$.

NKA stimulated PRL release from anterior pituitaries of estrus and proestrus rats, but had no effect in anterior

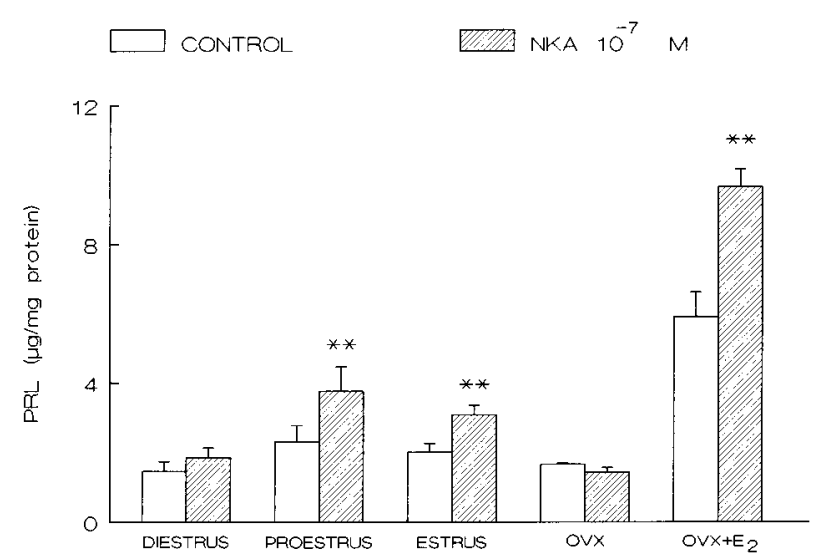

Figure 1 Effect of NKA on in vitro PRL secretion from incubated hemipituitaries of cyclic female rats, OVX and OVX-estradiol treated $\left(E_{2}\right)$ rats. Values represent means \pm S.E.M. of six or seven determinations per group. Data were evaluated by paired (cyclic rats) or unpaired (OVX rats) Student's $t$-test. ${ }^{* *} P<0.01$ compared with control without NKA.

pituitaries of diestrus rats (Fig. 1). In contrast, NKA significantly increased PRL secretion from anterior pituitaries of OVX rats chronically treated with estradiol, but had no effect on PRL release from pituitaries of OVX rats (Fig. 1).

Effect of estradiol on NKA-induced PRL release from cultured anterior pituitary cells of OVX rats

In order to determine whether anterior pituitary cells in culture would also respond to NKA, we tested the effect of NKA on PRL release from anterior pituitary cells of male rats. The presence of increasing concentrations of NKA in the incubation medium significantly stimulated PRL release from cultured anterior pituitary cells. This effect was dose-dependent (Fig. 2).

We then studied the in vitro effect of estradiol on the secretory response to NKA by cultured anterior pituitary cells of OVX rats. PRL release after $60 \mathrm{~min}$ of incubation was significantly greater in pituitary cells of OVX rats cultured for 3 days in the presence of $17 \beta$-estradiol $\left(10^{-9} \mathrm{M}\right)$ than in control cells. In contrast, NKA $\left(10^{-7} \mathrm{M}\right)$ significantly stimulated the secretion of PRL from anterior pituitary cells of OVX rats only if they were exposed to estradiol (Fig. 3).

To determine whether the NK-2 receptor subtype is involved in the action of NKA on PRL release, we studied the effect of an NK-2 receptor antagonist (L-659,877) on basal and NKA-induced PRL release from anterior pituitary cells of OVX rats. The presence of L-659,877 $\left(10^{-7}-10^{-5} \mathrm{M}\right)$ did not affect PRL secretion from pituitary cells of OVX rats (data not shown). However, although L-659,877 did not affect basal PRL release from pituitary cells of OVX rats cultured in the presence of 


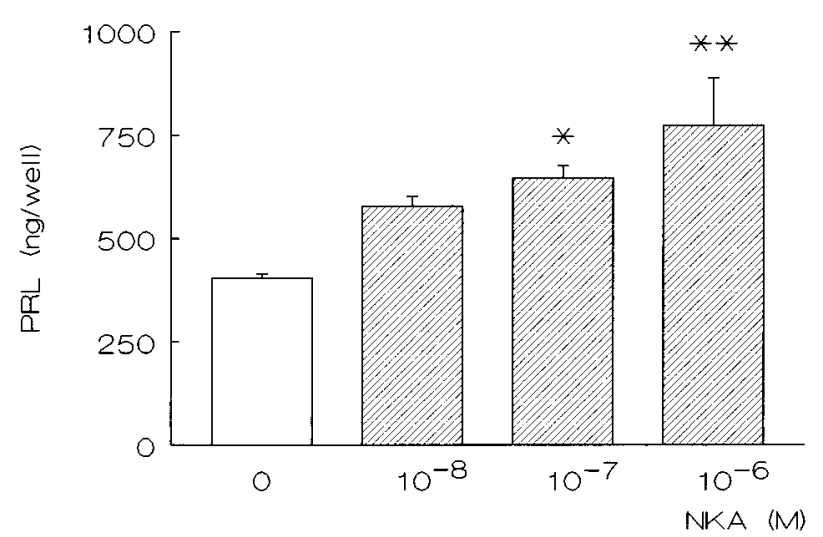

Figure 2 Effect of NKA on PRL secretion from cultured anterior pituitary cells of male rats. Values represent means \pm S.E.M. of five or six determinations per group. Data were evaluated by one-way ANOVA followed by Dunnett's test. ${ }^{*} P<0 \cdot 05,{ }^{*} P<0 \cdot 01$ compared with control without NKA.

estradiol, the NK-2 receptor antagonist blocked the stimulatory effect of NKA. The presence of L-659,877 plus NKA reduced PRL release below the values obtained with the antagonist alone (Table 1).

\section{Effect of NKA on anterior pituitary cells from lactating rats}

In order to investigate the influence of lactation on the effect of NKA on PRL secretion, we performed a study on cultured anterior pituitary cells of lactating rats. The mothers $(1,5,10$ or 20 days of lactation) were separated from their pups for $60 \mathrm{~min}$ before decapitation. After 3 days of culture, the anterior pituitary cells were incubated for $60 \mathrm{~min}$ with NKA $\left(10^{-8}-10^{-6} \mathrm{M}\right)$. NKA did not modify the release of PRL from cells of rats on day 1

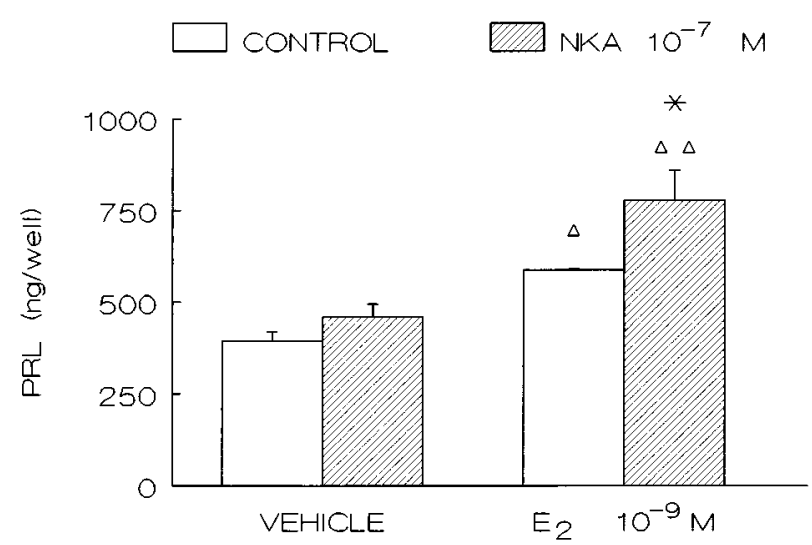

Figure 3 Effect of in vitro estradiol treatment $\left(\mathrm{E}_{2}\right)$ on the responsiveness to NKA of cultured anterior pituitary cells of OVX rats. Values represent means \pm S.E.M. of five determinations per group. Data were evaluated by two-way ANOVA followed by Tukey's test. $\triangle P<0 \cdot 05, \triangle \triangle P<0 \cdot 01$ compared with vehicle without estradiol; ${ }^{*} P<0.05$ compared with control without NKA. of lactation. Whereas only the highest concentration of NKA stimulated release of PRL from cultured cells of rats on day 5 of lactation, all the NKA concentrations assayed stimulated release of PRL from cells of rats on day 10 of lactation. NKA $\left(10^{-7}\right.$ and $\left.10^{-6} \mathrm{M}\right)$ also increased PRL secretion from cells of rats on day 20 of lactation (Fig. 4).

\section{Effect of ANKA on suckling-induced PRL surge}

To evaluate the role of endogenous NKA on circulating PRL concentrations induced by the suckling stimulus, we studied the effect of the blockade of NKA by the administration of an anti-NKA serum in rats on day 10 of lactation. The suckling stimulus increased serum PRL concentrations in animals injected with NRS. The blockade of endogenous NKA by the administration of ANKA significantly decreased the concentrations of PRL induced by suckling, but did not modify PRL concentrations in non-suckled controls (Fig. 5).

\section{Discussion}

The present study showed that NKA stimulates PRL secretion at the pituitary level in female rats, and that this action may be modulated by the hormonal milieu.

We have previously reported that, even though NKA increased the release of PRL from incubated anterior pituitaries of male rats, this tachykinin did not modify the release of PRL from pituitaries of OVX rats (Pisera et al. 1994). In accordance with our previous observations, the present results show that NKA does not modify the release of PRL from anterior pituitary of OVX rats. However, NKA stimulates PRL secretion at the pituitary level in OVX-estrogenized rats. These results are in agreement with the hypothesis that gonadal steroids would be necessary for the response of the anterior pituitary to NKA. The fact that NKA stimulated PRL release when the anterior pituitary cells from OVX rats were cultured in the presence of estradiol suggests that estrogens may exert an enabling action at the pituitary level. Indeed, it has been reported that estradiol modulates the responsiveness of lactotropes to other PRL-releasing peptides such as TRH (Giguere et al. 1982) and VIP (Pizzi et al. 1991). In the male rat, endogenous concentrations of sex steroids could be high enough to induce an NKA action.

As the in vivo effects of the blockade of endogenous NKA were observed only in female rats with high concentrations of estradiol (Pisera et al. 1991), we evaluated the in vitro effect of this tachykinin throughout the estrus cycle and thus in the presence of different circulating concentrations of gonadal steroids. In this respect, we observed that NKA stimulates the in vitro secretion of PRL from anterior pituitaries of proestrus rats, when the endogenous concentrations of estradiol are high. The stimulatory action of NKA on PRL release from anterior 
Table 1 Effect of L-659,877 on NKA-induced PRL secretion from anterior pituitary cells of OVX rats cultured with or without $17 \beta$-estradiol for 3 days. Values represent the mean \pm S.E.M. (number of determinations).

\begin{tabular}{|c|c|c|}
\hline & PRL (ng/well) & \\
\hline & Vehicle & $17 \beta$-Estradiol $\left(10^{-9} \mathrm{M}\right)$ \\
\hline Control & $241 \cdot 96 \pm 14 \cdot 64(5)$ & $698 \cdot 60 \pm 27 \cdot 00(6)$ \\
\hline NKA $\left(10^{-7} \mathrm{M}\right)$ & $277 \cdot 08 \pm 27 \cdot 80$ & $807 \cdot 72 \pm 15 \cdot 80(6)^{* *}$ \\
\hline L-659,877 $\left(10^{-6} \mathrm{M}\right)$ & $249 \cdot 12 \pm 19 \cdot 28$ & $756 \cdot 44 \pm 17 \cdot 60(6)$ \\
\hline NKA+L-659,877 & $243 \cdot 08 \pm 19 \cdot 28(5)$ & $655 \cdot 72 \pm 19 \cdot 86(6)^{\star *}+\dagger$ \\
\hline
\end{tabular}

${ }^{*} P<0 \cdot 01$ compared with control without NKA, $+\dagger P<0 \cdot 01$ compared with control without L-659,877 (two-way ANOVA followed by Tukey's test).

pituitaries of estrus rats may be explained by the sustained effect of the proestrus estradiol surge on pituitary cells. These results suggest that physiological changes in circulating concentrations of estradiol could modulate the action of NKA on PRL release. It has been reported that hypothalamic and anterior pituitary synthesis of tachykinins is modulated by gonadal steroids (Brown et al. 1990). Estradiol reduces the concentration of NKA in the anterior pituitary gland, but increases it in the whole hypothalamus and in the median eminence-arcuate nucleus (Debeljuk et al. 1992a). In fact, the anterior pituitary and hypothalamic concentrations of tachykinins change during the estrus cycle (Tsuruo et al. 1987, Debeljuk et al. 1990, 1992b, Duval et al. 1996), and it has been suggested that the decrease in hypothalamic concentration of tachykinins on the proestrus day may be explained by the high rates of release of these peptides (Tsuruo et al. 1987, Jarry et al. 1988). Moreover, the number of anterior pituitary substance P-binding sites changes over the estrus cycle, and reaches the highest levels during the day of proestrus (Kerdelhué et al. 1985). All these observations suggest the possibility that actions of NKA change over the estrus cycle. Taken together, these data support the hypothesis that NKA, produced locally in the anterior pituitary or transported from the hypothalamus through the portal system, may participate in the generation of the proestrus PRL surge, acting on estrogen-sensitized anterior pituitary cells.
DAY 1

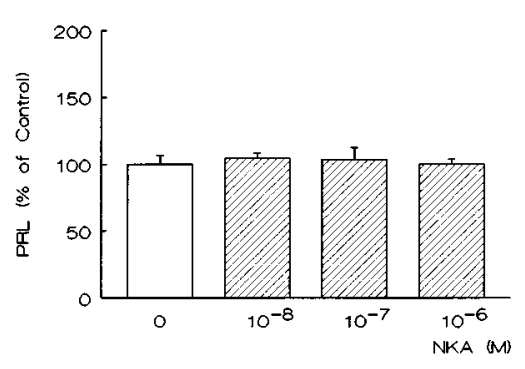

DAY 10

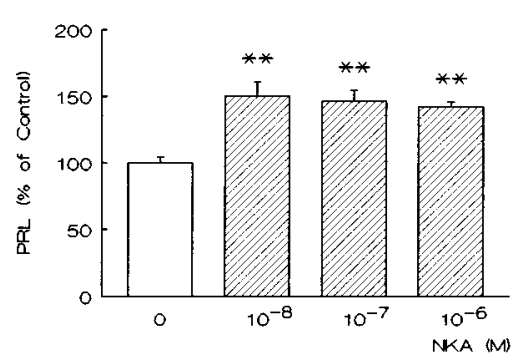

DAY 5

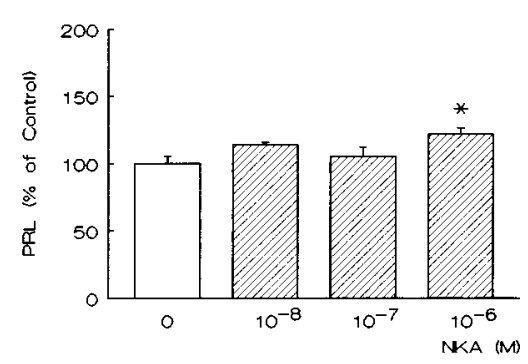

DAY 20

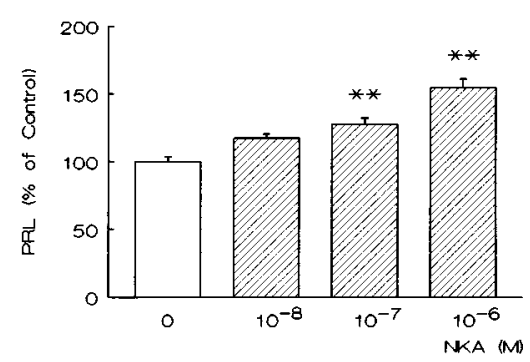

Figure 4 Effect of NKA on PRL secretion from cultured anterior pituitary cells of rats killed at different days of lactation. Values represent means \pm S.E.M. of six to eight determinations per group. Data were evaluated by one-way ANOVA followed by Dunnett's test. ${ }^{*} P<0 \cdot 05$, ${ }^{* *} P<0 \cdot 01$ compared with control without NKA. 


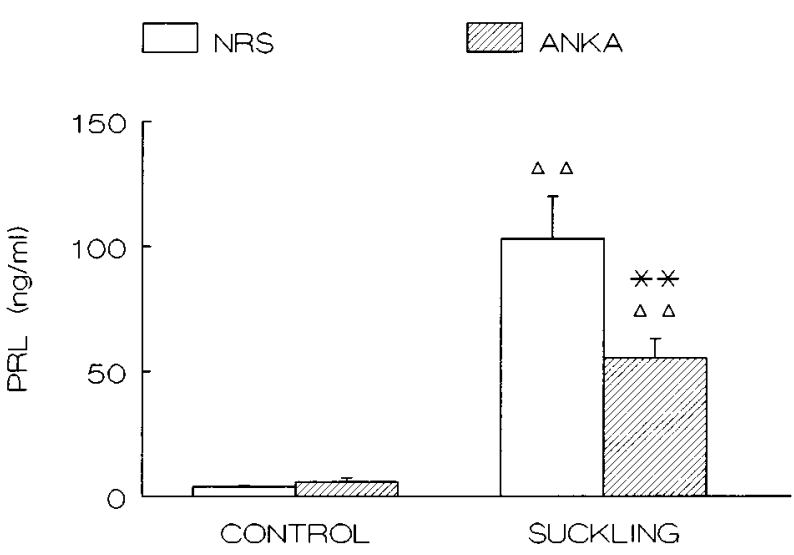

Figure 5 Effect of an anti-NKA serum (ANKA) administration on circulating PRL concentrations induced by suckling. Values represent means \pm S.E.M. of eight determinations per group. Data were evaluated by two-way ANOVA followed by Tukey's test. ${ }^{*} P<0 \cdot 01$ compared with respective control injected with normal rabbit serum (NRS); $\triangle \triangle P<0.01$ compared with respective non-suckled controls.

As regards the lactation period, the responsiveness of anterior pituitary cells to NKA was variable and reached the maximal expression on day 10. As serum concentrations of estradiol and progesterone increase during the postpartum period (Arbogast \& Voogt 1996), the action of gonadal steroids may be involved in the modulation of the response of pituitary cells to NKA during lactation. In addition, as it has been reported that the suckling stimulus increases the number of lactotropes responsive to TRH and angiotensin II (Nagy \& Frawley 1990), the cumulative effect of suckling could also play a part in the sensitivity of pituitary cells to NKA. Several studies have shown that the suckling stimulus has an inhibitory effect on tuberoinfundibular dopaminergic neurons of lactating rats (Arbogast \& Voogt 1996), and that a decrease in dopamine inputs is necessary for the action of TRH on PRL release (Shanti et al. 1995). Thus, suckling stimuli appear to prepare the anterior pituitary cells to respond to several PRL-releasing peptides. Our studies also show a reduction in the effect of NKA on day 20 of lactation. With advancing lactation there is a decrease in the magnitude of the PRL response to suckling (McNeilly 1994), and the refractoriness in anterior pituitary cells to PRL-releasing stimuli could be at least partially responsible for the decline in suckling-induced PRL release in late lactation (Shanti et al. 1995).

The reduction of suckling-induced serum concentrations of PRL observed in rats injected with ANKA indicates that endogenous NKA may have a role in the generation of high concentrations of PRL induced by this stimulus. We reported a similar finding in lactating rats injected with an anti-substance P serum (Debeljuk et al. 1988). Moreover, the hypothalamic content of substance $P$ increases during the suckling stimulus (Isovich et al. 1994).
These data suggest that endogenous tachykinins may be involved in the hyperprolactinemia induced by suckling.

Binding studies have shown that NK-1 receptors are present in lactotropes and gonadotropes (Larsen et al. 1992). Although NKA has a greater affinity for the NK-2 than for the NK-1 tachykinin receptor subtype, the naturally occurring tachykinins show poor selectivity and they can act as full agonists of the three receptor subtypes (Regoli et al. 1994). The NK-2 receptor subtype has not been characterized in the anterior pituitary (Larsen et al. 1989). However, Kalra et al. (1992) have suggested that the effects of NPK on the in vitro release of luteinizing hormone may be mediated by pituitary NK-2 receptors. Our observation that the effect of NKA on the release of PRL from anterior pituitary cells exposed to estradiol is blocked by L-659,877 (a specific NK-2 receptor antagonist) strongly suggests that this NKA action is also mediated by the NK-2 receptor subtype.

In summary, the present findings strongly suggest that NKA may be involved in the control of release of PRL, acting as a stimulatory factor at the pituitary level. Our results show that the effect of NKA on PRL secretion in female rats is modulated by the hormonal environment and that NKA may be involved in the control of PRL secretion during the estrus cycle and lactation.

\section{Acknowledgements}

We gratefully acknowledge the technical support provided by Mr Miguel Velardez and Dr María del Carmen Díaz. In addition, we are thankful to Dr Luciano Debeljuk for the characterization of the anti-NKA serum. This work was supported by grants from Consejo Nacional de Investigaciones Científicas y Técnicas (CONICET) and Universidad de Buenos Aires, Argentina.

\section{References}

Arbogast LA \& Voogt JL 1996 The responsiveness of tuberoinfundibular dopaminergic neurons to prolactin feedback is diminished between early lactation and midlactation in the rat. Endocrinology 137 47-54.

Brown ER, Harlan RE \& Krause JE 1990 Gonadal steroids regulation of substance $\mathrm{P}(\mathrm{SP})$ and $\mathrm{SP}$-encoding messenger ribonucleic acids in the rat anterior pituitary and hypothalamus. Endocrinology 126 330-340.

Debeljuk L, Lasaga M, Afione S, Duvilanski B \& Díaz MC 1988 Effect of passive immunization against substance $\mathrm{P}$ in rats with hyperprolactinemia. Peptides 9 933-936.

Debeljuk L, Villanúa MA \& Bartke A 1990 Neurokinin A in the hypothalamus and anterior pituitary during the estrous cycle in the golden hamster. Neuroscience Letters 120 253-255.

Debeljuk L, Villanúa MA \& Bartke A 1992a Neurokinin A in the anterior pituitary of female rats: effects of ovariectomy and estradiol. Peptides 13 1001-1005.

Debeljuk L, Villanúa MA \& Bartke A $1992 b$ Substance P variations in the hypothalamus of golden hamster at different stages of the estrous cycle. Neuroscience Letters 137 178-180. 
Duval P, Lenoir V, Moussaoui S, Garret C \& Kerdelhué B 1996 Substance $\mathrm{P}$ and neurokinin A variations throughout the rat estrous cycle; comparison with ovariectomized and male rats: I. Plasma, hypothalamus, anterior and posterior pituitary. Journal of Neuroscience Research 45 598-609.

Giguere V, Meunier H, Veilleux R \& Labrie F 1982 Direct effects of sex steroids on prolactin release at the anterior pituitary level: interaction with dopamine, thyrotropin-releasing hormone, and isobutylmethylxanthine Endocrinology 111 857-862.

Isovich E, Díaz MC, Lasaga M, Pisera D, Zambruno C, Theas MS, Seilicovich A \& Duvilanski B 1994 Involvement of substance P in the effect of prolactin on dopamine release. Neuroreport $\mathbf{5}$ $1752-1754$

Jarry H, Perschl A, Meissner H \& Wuttke W 1988 In vivo release rates of substance $\mathrm{P}$ in the preoptic/anterior hypothalamic area of ovariectomized and ovariectomized estrogen-primed rats: correlation with luteinizing hormone and prolactin levels. Neuroscience Letters $\mathbf{8 8}$ 189-194.

Kalra PS, Sahu A, Bonavera JJ \& Kalra SP 1992 Diverse effects of tachykinins on luteinizing hormone release in male rats: mechanism of action. Endocrinology 131 1195-1201.

Kerdelhué B, Tartar A, Lenoir V, El Abed A, Hublau P \& Millar RP 1985 Binding studies of substance P anterior pituitary binding sites: changes in substance $\mathrm{P}$ binding sites during the rat estrous cycle. Regulatory Peptides 10 133-143.

Kordon C, Drouva SV, Martinez de la Escalera G \& Weiner RI 1994 Role of classic and peptide neuromediators in the neuroendocrine regulation of luteinizing hormone and prolactin. In The Physiology of Reproduction I, edn 2, pp 1621-1681. Eds E Knobil \& JD Neill. New York: Raven Press.

Larsen P, Mikkelsen J \& Særmark T 1989 Binding of a iodinated substance $\mathrm{P}$ analog to a NK-1 receptor on isolated cell membranes from rat anterior pituitary. Endocrinology 124 2548-2557.

Larsen P, Særmark T \& Mau S 1992 Binding of an iodinated substance $\mathrm{P}$ analogue to cultured anterior pituitary prolactin- and luteinizing hormone-containing cells. Journal of Histochemistry and Cytochemistry 40 487-493.

Lowry OH, Rosebrough NJ, Farr AL \& Randall RJ 1951 Protein measurement with the folin phenol reagent. Journal of Biological Chemistry 193 265-275.
McNeilly AS 1994 Suckling and the control of gonadotropin secretion. In The Physiology of Reproduction II, edn 2, pp 1179-1212. Eds E Knobil \& JD Neill. New York: Raven Press.

Maggi CA 1995 The mammalian tachykinin receptors. General Pharmacology 26 911-944.

Nagy GM \& Frawley LS 1990 Suckling increases the proportions of mammotropes responsive to various prolactin-releasing stimuli. Endocrinology 127 2079-2084.

Pisera D, Debeljuk L, Seilicovich A, Afione S, Duvilanski B, Díaz MC, Lasaga M, Traktemberg R \& Bartke A 1991 Possible role of neurokinin $\mathrm{A}$ in the control of prolactin secretion in rats and hamsters. Journal of Neuroendocrinology 3 279-283.

Pisera D, Duvilanski B, Lasaga M, Díaz MC \& Seilicovich A 1994 Stimulation of prolactin release by neurokinin A in vitro. Neuroendocrinology Letters 16 241-246.

Pizzi M, Rubessa S, Simonazzi E, Zanagnolo V, Falsetti L, Memo M \& Spano PF 1991 Requirement of oestrogens for the sensitivity of prolactin cells to vasoactive intestinal peptide in rats and man. Journal of Endocrinology 132 311-316.

Regoli D, Boudon A \& Fauchére JL 1994 Receptors and antagonists for substance P and related peptides. Pharmacological Reviews $\mathbf{4 6}$ $551-599$

Sahu A \& Kalra SP 1992 Effects of tachykinins on luteinizing hormone release in female rats: potent inhibitory action of neuropeptide K. Endocrinology 130 1571-1577.

Shamgochian MD \& Leeman SE 1992 Substance P stimulates luteinizing hormone secretion from anterior pituitary cells in culture. Endocrinology 131 871-875.

Shanti AS, Subramanian MG, Savoy-Moore RT, Kruger ML \& Moghissi KS 1995 Attenuation of the magnitude of sucklinginduced prolactin release with advancing lactation: mechanisms. Life Sciences 56 259-266.

Tsuruo Y, Hisano S, Nakanishi J, Katoh S \& Daikoku S 1987 Immunohistochemical studies on the roles of substance $\mathrm{P}$ in the rat hypothalamus: possible implication in the hypothalamichypophysial-gonadal axis. Neuroendocrinology 45 389-401.

Received 16 March 1998

Accepted 13 July 1998 